\title{
Experimental study on optimization of water reducer in pumping concrete
}

\author{
Yuan Qiansheng \\ XiChang College, Xichang, Sichuan, China \\ email:xcac@163.com
}

\begin{abstract}
Keywords: water reducer; naphthalene-based type; polycarboxylate-based type; pumping concrete Abstract. The different water reducers have different suitability and different influence of performance with concrete mixture. Combined with the engineering practice, 3 kinds of naphthalene-based water reducer (NSR) and 4 kinds of polycarboxylate-based water reducer (PC) were selected as the objects. The saturation dosage of water reducers was determined by single factor test. Using the concrete standard mixture in the saturated dosage of the water reducer, the pumping concrete slump loss, gas loss, bleeding rate, setting time and separation properties about the 7 kinds of water reducers under the state of the coarse aggregate saturated surface dried and air dried were tested in order to select 4 of the adaptability of water reducer. By testing 4 kinds of water reducers, it's shown that the performance of concrete mixed with water reducer is optimal after 60 minutes.
\end{abstract}

\section{Introduction}

Pumping concrete with naphthalene-based water reducer and polycarboxylate-based water reducer are mainly used in the western concrete engineering of JinpingII hydropower station working. There are some issues: the naphthalene-based of concrete mixing has a big slump loss, and it takes a long time to condensation and makes the pumping concrete tube blocked. The polycarboxylate-based brings too much air bubbles which affects the quality and appearance of the concrete. The influences of the water reducers on concrete were proved and the future trend was also discussed ${ }^{[1 \sim 9]}$. By adding admixtures, the durability of concrete with different gelled material was also analyzed ${ }^{[10]}$. However, there are few comparative analysis on performance of pumping concrete of both naphthalene-based and polycarboxylate-based water reducers. Hence, it is necessary to study the influence of these two water reducers in engineering practice.

\section{The raw materials}

2.1 Cement, fly ash, aggregate. Test material and engineering field are same. The cement is "E-sheng" P.O42.5 which meets the requirements of specification and the engineering design requirements on the performance indicators. The fly ash is "MingchuanII" by Guizhou province which also meets the specification requirements on chemical composition and physical properties. And the inspection indexes meet the requirements of engineering project for class II fly ash except ignition loss. The indexes of artificial sand and gravel meet the specification requirements.

\subsection{Admixture}

\subsubsection{Water reducer}

(1) naphthalene-based water reducer

Three brands of naphthalene-based water reducer are used to study the influence of working performance with different water reducers: JG-3 by Beijing Metallurgical Construction co., LTD, HLC-NAF by Nanjing Ruidi high-tech co., LTD, JM-II(C) by Jiangsu Bote new materials co., LTD.

(2) polycarboxylate-based water reducer

Four brands of polycarboxylate-based water reducer are used: JG-2H by Beijing Metallurgical Construction co., LTD, HLC-IX by Nanjing Ruidi high-tech co., LTD, JM-PCA(I) by Jiangsu Bote new materials co., LTD, NOF-AS by Shandong Huawei silver kay building materials technology co., LTD.

(3) The air-entraining agent 
The air-entraining agent is HJAE-A by the Yellow River new chemical co., LTD. and the indicators meet the specification requirements.

\section{The experimental study on the dosage of saturated water reducer}

Referring to the test methods of the fluidity of cement paste, single factor experiment method is used to determine the saturation dosage for different water reducers. Cement $240 \mathrm{~g}$, fly ash $60 \mathrm{~g}$, water $87 \mathrm{~g}$ are for each set of test and the dosages of water reducers are respectively $0.5 \%, 0.6 \%$ 、 $0.7 \%, 0.8 \%, 0.9 \%, 1.0 \%$. The results of the tests are shown in table 1 .

Table 1 The fluidity of cement paste by different amounts of water reducer Unit: $\mathrm{mm}$

\begin{tabular}{cllllll}
\hline \multirow{2}{*}{ Types of water reducers } & \multicolumn{7}{c}{ Amount /\% } \\
\cline { 2 - 7 } & 0.5 & 0.6 & 0.7 & 0.8 & 0.9 & 1.0 \\
\hline JG-3 & 131 & 144 & 208 & 230 & 240 & 242 \\
HLC-NAF & 152 & 197 & 221 & 246 & 245 & 235 \\
JM-II(c) & 145 & 188 & 208 & 229 & 228 & 226 \\
JG-2H & 238 & 276 & 290 & 296 & 292 & 290 \\
NOF-AS & 223 & 240 & 249 & 268 & 270 & 275 \\
JM-PCA(I) & 228 & 260 & 275 & 278 & 278 & 280 \\
HLC-IX & 236 & 257 & 270 & 275 & 275 & 273 \\
\hline
\end{tabular}

According to table 1, the saturation dosages of the seven kinds of water reducers which are JG-3、HLC-NAF、JM-II（c）、JG-2H、NOF-AS、JM-PCA（I） and HLC-IX and the amounts are respectively $0.9 \%, 0.8 \%, 0.8 \%, 0.7 \%, 0.8 \%, 0.7 \%$ and $0.7 \%$.

The fluidity of cement pastes with different times under the dosage saturated of water reducers are in table 2.

Table 2 The fluidity of cement paste with different times Unit: $\mathrm{mm}$

\begin{tabular}{cccccccc}
\hline $\begin{array}{c}\text { Types of water } \\
\text { reducers }\end{array}$ & 0 & 15 & 30 & 45 & 60 & 90 & 120 \\
\cline { 2 - 7 } & 255 & 250 & 245 & 245 & 245 & 245 & 245 \\
\hline JG-3 & 230 & 228 & 224 & 218 & 222 & 225 & 224 \\
HLC-NAF & 240 & 237 & 238 & 238 & 235 & 235 & 237 \\
JM-II (c) & 288 & 282 & 289 & 280 & 282 & 280 & 278 \\
JG-2H & 275 & 270 & 270 & 270 & 272 & 275 & 272 \\
NOF-AS & 274 & 270 & 270 & 272 & 275 & 274 & 271 \\
JM-PCA (I) & 278 & 275 & 275 & 275 & 270 & 275 & 275 \\
HLC-IX & 270
\end{tabular}

Table 2 shows that the fluidities of the cement paste are without lost within 2 hours by the naphthalene-based and polycarboxylate-based water reducers. Therefore, the saturation dosages of the seven types of water reducers are reasonable.

\section{The influences of the mixture by water reducer and the situation of the aggregate}

The test takes the concrete construction mixture ratio (C25W8F100) of the western water tunnel engineering of the JinpingII hydropower station as the basic ratio. The water-cement ratio is 0.42 ; sand ratio is $40 \%$; fly ash is $20 \%$; and the ratio of little-middle rock is 60:40. The dosage of air-entraining agent based on the gas content is 3\% 5\% of the control standard. Analysis the affect on the slump, gas content, exudation rate and setting time with two states of the water reducer are determined.

\subsection{The saturated surface dried state of coarse aggregate}

4.1.1 The influence of water reducer for saturated surface dried concrete mixture ratio with the coarse aggregate. Make sure that the coarse aggregate for the saturated surface dry state, and the water/cement ratio and sand ratio stay the same to determine the dosage of different water 
reducers and air-entraining agents based on the same workability of the concrete mixture. The results of the tests are in table 3.

Table 3. The amount of additive in standard mixture of concrete

\begin{tabular}{cccccccccc}
\hline \multirow{2}{*}{$\begin{array}{c}\text { Types of } \\
\text { water } \\
\text { reducers }\end{array}$} & $\begin{array}{c}\text { Water } \\
\text { cement } \\
\text { ratio }\end{array}$ & Water & $\begin{array}{c}\text { The } \\
\text { amount } \\
\text { of flyash } \\
/ \%\end{array}$ & $\begin{array}{c}\text { Total } \\
\text { binding } \\
\text { material } \\
/\left(\mathrm{kg} / \mathrm{m}^{3}\right)\end{array}$ & $\begin{array}{c}\text { The } \\
\text { dosag } \\
\text { e of } \\
\text { water } \\
\text { reduc } \\
\text { er/\% }\end{array}$ & $\begin{array}{c}\text { Air } \\
\text { entrain } \\
\text { ing } \\
\text { agent } \\
/\left(10^{-4}\right)\end{array}$ & $\begin{array}{c}\text { Slump } \\
/(\mathrm{mm})\end{array}$ & $\begin{array}{c}\text { Gas } \\
\text { content } \\
/ \%\end{array}$ & $\begin{array}{c}\text { Diffusion } \\
/(\mathrm{mm})\end{array}$ \\
\hline JG-3 & 0.42 & 133 & 20 & 317 & 0.8 & 0.18 & 180 & 3.6 & 300 \\
JM-II (c) & 0.42 & 130 & 20 & 310 & 0.6 & 0.18 & 190 & 4.2 & 340 \\
HLC-NAF & 0.42 & 133 & 20 & 317 & 0.8 & 0.37 & 198 & 3.6 & 350 \\
NOF-AS & 0.42 & 123 & 20 & 293 & 0.6 & 0.17 & 210 & 4.6 & 480 \\
JG-2H & 0.42 & 123 & 20 & 293 & 0.6 & 0.36 & 204 & 3.4 & 490 \\
JM-PCA (I) & 0.42 & 123 & 20 & 293 & 0.6 & 0.53 & 205 & 4.1 & 410 \\
HLC-IX & 0.42 & 123 & 20 & 293 & 0.6 & 0.70 & 205 & 3.4 & 480 \\
\hline
\end{tabular}

The water consumption of the concrete with naphthalene-based water reducer is higher than 10 $\mathrm{kg} / \mathrm{m}^{3}$ than polycarboxylate-based water reducer. Maintain the same workability based on the same water-cement ratio of concrete. There is an increasing trend of the dosages of air-entraining agent in the concrete which mixed by polycarboxylate-based water reducers because of too much Defoamer in the water reducer. The flowability of concrete which mixed with polycarboxylate-based water reducer is better than naphthalene-based water reducer.

4.1.2 The test of the water reducer under the coarse aggregate saturated surface dried. According to the mixing amount of the table 3 of the water reducers, the influences of concrete on the slump loss, gas loss, bleeding rate and the setting time with different water reducers are analyzed. The results of the test are in the table 4 (SL- slump loss rate, G- gas content loss rate, the same below).

Table 4 The test result of coarse aggregate in saturated surface dry condition

\begin{tabular}{|c|c|c|c|c|c|c|c|c|c|c|c|c|c|c|c|c|c|c|c|}
\hline \multirow{3}{*}{$\begin{array}{l}\text { Water } \\
\text { reducer }\end{array}$} & \multirow{3}{*}{$\begin{array}{l}\text { The } \\
\text { mach } \\
\text { ine } \\
\text { slum } \\
\text { p } \\
/ \mathrm{mm}\end{array}$} & \multirow{3}{*}{$\begin{array}{c}\text { Initial } \\
\text { gas } \\
\text { conte } \\
\text { nt } \\
1 \% \\
\end{array}$} & \multicolumn{14}{|c|}{ Time /min } & \multirow{3}{*}{$\begin{array}{l}\text { Bleed } \\
\text { ing } \\
\text { rate } \\
1 \%\end{array}$} & \multicolumn{2}{|c|}{$\begin{array}{l}\text { Setting } \\
\text { time } \\
/ \mathrm{min}\end{array}$} \\
\hline & & & \multicolumn{2}{|c|}{0} & \multicolumn{2}{|c|}{15} & \multicolumn{2}{|c|}{30} & \multicolumn{2}{|c|}{45} & \multicolumn{2}{|c|}{60} & \multicolumn{2}{|c|}{90} & \multicolumn{2}{|c|}{120} & & \multirow{2}{*}{$\begin{array}{c}\text { Initi } \\
\text { al } \\
\text { setti } \\
\text { ng }\end{array}$} & \multirow{2}{*}{$\begin{array}{c}\text { Fin } \\
\text { al } \\
\text { setti } \\
\text { ng }\end{array}$} \\
\hline & & & $\begin{array}{l}\mathrm{S} \\
\mathrm{L}\end{array}$ & G & $\begin{array}{l}\mathrm{S} \\
\mathrm{L}\end{array}$ & G & $\begin{array}{l}\mathrm{S} \\
\mathrm{L}\end{array}$ & G & $\begin{array}{l}\mathrm{S} \\
\mathrm{L}\end{array}$ & G & $\begin{array}{l}\mathrm{S} \\
\mathrm{L}\end{array}$ & $\mathrm{G}$ & $\begin{array}{l}\mathrm{S} \\
\mathrm{L}\end{array}$ & G & $\begin{array}{l}\mathrm{S} \\
\mathrm{L}\end{array}$ & G & & & \\
\hline JG-3 & 180 & 3.6 & 0 & 0 & $\begin{array}{l}4 \\
9\end{array}$ & $\begin{array}{l}1 \\
1\end{array}$ & $\begin{array}{l}5 \\
8\end{array}$ & $\begin{array}{l}4 \\
2\end{array}$ & $\begin{array}{l}6 \\
4\end{array}$ & $\begin{array}{l}4 \\
7\end{array}$ & $\begin{array}{l}6 \\
7\end{array}$ & $\begin{array}{l}4 \\
7\end{array}$ & 75 & $\begin{array}{l}5 \\
0\end{array}$ & $\begin{array}{l}8 \\
3\end{array}$ & 50 & 8.7 & 621 & 809 \\
\hline $\begin{array}{l}\text { JM-II } \\
\text { (c) }\end{array}$ & 190 & 4.2 & 0 & 0 & $\begin{array}{l}1 \\
8\end{array}$ & $\begin{array}{l}2 \\
7\end{array}$ & $\begin{array}{l}5 \\
0\end{array}$ & $\begin{array}{l}5 \\
4\end{array}$ & $\begin{array}{l}6 \\
1\end{array}$ & $\begin{array}{l}5 \\
4\end{array}$ & $\begin{array}{l}7 \\
1\end{array}$ & $\begin{array}{l}5 \\
4\end{array}$ & 83 & $\begin{array}{l}5 \\
4\end{array}$ & $\begin{array}{l}8 \\
4\end{array}$ & 56 & 10.4 & 778 & 900 \\
\hline $\begin{array}{l}\text { HLC- } \\
\text { NAF }\end{array}$ & 198 & 3.6 & 0 & 0 & $\begin{array}{l}2 \\
3\end{array}$ & $\begin{array}{l}2 \\
9\end{array}$ & $\begin{array}{l}4 \\
9\end{array}$ & $\begin{array}{l}3 \\
7\end{array}$ & $\begin{array}{l}6 \\
2\end{array}$ & $\begin{array}{l}5 \\
5\end{array}$ & $\begin{array}{l}6 \\
5\end{array}$ & $\begin{array}{l}5 \\
5\end{array}$ & 70 & $\begin{array}{l}5 \\
5\end{array}$ & $\begin{array}{l}7 \\
6\end{array}$ & 55 & 4.5 & 504 & 634 \\
\hline $\begin{array}{c}\text { NOF- } \\
\text { AS }\end{array}$ & 210 & 4.6 & 0 & 0 & 8 & $\begin{array}{l}5 \\
7\end{array}$ & $\begin{array}{l}1 \\
1\end{array}$ & $\begin{array}{l}7 \\
7\end{array}$ & $\begin{array}{l}4 \\
1\end{array}$ & $\begin{array}{l}7 \\
7\end{array}$ & $\begin{array}{l}6 \\
0\end{array}$ & $\begin{array}{l}7 \\
7\end{array}$ & 89 & $\begin{array}{l}7 \\
7\end{array}$ & $\begin{array}{l}9 \\
0\end{array}$ & 77 & 7.0 & 518 & 702 \\
\hline JG-2H & 204 & 3.4 & 0 & 0 & 4 & $\begin{array}{l}1 \\
1\end{array}$ & $\begin{array}{l}4 \\
6\end{array}$ & $\begin{array}{l}1 \\
1\end{array}$ & $\begin{array}{l}7 \\
1\end{array}$ & $\begin{array}{l}1 \\
1\end{array}$ & $\begin{array}{l}8 \\
2\end{array}$ & $\begin{array}{l}1 \\
1\end{array}$ & 89 & $\begin{array}{l}1 \\
1\end{array}$ & $\begin{array}{l}9 \\
1\end{array}$ & 11 & 7.6 & 567 & 747 \\
\hline $\begin{array}{c}\text { JM-PC } \\
\text { A(I) }\end{array}$ & 205 & 4.1 & 0 & 0 & 0 & 7 & 0 & $\begin{array}{l}1 \\
5\end{array}$ & $\begin{array}{l}2 \\
0\end{array}$ & $\begin{array}{l}2 \\
0\end{array}$ & $\begin{array}{l}5 \\
1\end{array}$ & $\begin{array}{l}2 \\
2\end{array}$ & 71 & $\begin{array}{l}2 \\
2\end{array}$ & $\begin{array}{l}8 \\
3\end{array}$ & 22 & 5.7 & 525 & 675 \\
\hline $\begin{array}{c}\text { HLC-I } \\
\text { X }\end{array}$ & 205 & 3.4 & 0 & 0 & 0 & $\begin{array}{l}1 \\
8\end{array}$ & $\begin{array}{l}1 \\
0\end{array}$ & $\begin{array}{l}1 \\
8\end{array}$ & $\begin{array}{l}4 \\
6\end{array}$ & $\begin{array}{l}1 \\
8\end{array}$ & $\begin{array}{l}5 \\
8\end{array}$ & $\begin{array}{l}1 \\
8\end{array}$ & 73 & $\begin{array}{l}1 \\
8 \\
\end{array}$ & $\begin{array}{l}8 \\
6\end{array}$ & 18 & 6.7 & 400 & 534 \\
\hline
\end{tabular}

The gas content loss rate of the concrete is higher during mixed 0 30mins with naphthalene-based water reducers. However it tends to reduce after $55 \mathrm{mins}$. The gas content loss rates of the concrete are lower which mixed with polycarboxylate-based water reducers rather than naphthalene-based water reducers except NOF-AS. The slump loss rates of the concrete within 30 mins after mixing are better than which mixed by polycarboxylate-based which are increased after mixing 60mins. Until 120mins after mixing, they are close to the naphthalene-based water reducers' slump loss rates.

4.2 The state of coarse aggregate air dried. Based on the engineering practice, analyze the adaptability of the concrete mixing and the water reducers when the coarse aggregate air dries. 
Adjusting the water according to the mixing content slump under the condition that the amount of the cementing material and admixture are consistent with mixing design ratio. Make sure that the concrete strengths are all the same regardless of the coarse aggregate saturated surface dried or air dried.

4.2.1 The influence of water reducer for the concrete mixture ratio with coarse aggregate air dried. Make sure that the coarse aggregate is air dried. Take sand ratio fixed at $40 \%$. The amount of the cementing material and admixture are consistent with the coarse aggregate saturated surface dried, adjusting the water according to the workability only.

Table 5 The amount of additive in standard mix of concrete with saturated surface dry condition

\begin{tabular}{|c|c|c|c|c|c|c|c|c|c|}
\hline \multirow[b]{2}{*}{$\begin{array}{l}\text { Types of water } \\
\text { reducer }\end{array}$} & \multicolumn{4}{|c|}{ Basic parameters of mix } & \multirow{2}{*}{$\begin{array}{c}\text { The } \\
\text { amount of } \\
\text { water } \\
\text { reducing } \\
\text { agents/ } \\
(\%)\end{array}$} & \multirow[b]{2}{*}{$\begin{array}{c}\text { Air } \\
\text { entrainin } \\
\text { g agent } \\
/\left(10^{-4}\right)\end{array}$} & \multirow[b]{2}{*}{$\begin{array}{l}\text { Slump } \\
\text { /(mm) }\end{array}$} & \multirow[b]{2}{*}{$\begin{array}{c}\text { Gas } \\
\text { content } \\
1 \%\end{array}$} & \multirow[b]{2}{*}{$\begin{array}{c}\text { Diffusio } \\
\mathrm{n} \\
/(\mathrm{mm})\end{array}$} \\
\hline & $\begin{array}{l}\text { Water } \\
\text { cement } \\
\text { ratio }\end{array}$ & Water & $\begin{array}{l}\text { The } \\
\text { amount of } \\
\text { flyash } / \%\end{array}$ & $\begin{array}{c}\text { Total } \\
\text { amounts of } \\
\text { Cementitious/ } \\
\left(\mathrm{kg} / \mathrm{m}^{3}\right)\end{array}$ & & & & & \\
\hline JG-3 & 0.42 & 141 & 20 & 317 & 0.8 & 0.18 & 195 & 3.0 & 320 \\
\hline JM-II（c） & 0.42 & 138 & 20 & 310 & 0.6 & 0.18 & 178 & 3.9 & 340 \\
\hline HLC-NAF & 0.42 & 141 & 20 & 317 & 0.8 & 0.37 & 186 & 3.0 & 325 \\
\hline NOF-AS & 0.42 & 130 & 20 & 293 & 0.6 & 0.17 & 208 & 4.5 & 480 \\
\hline JG-2H & 0.42 & 130 & 20 & 293 & 0.6 & 0.36 & 190 & 3.2 & 460 \\
\hline JM-PCA（I） & 0.42 & 130 & 20 & 293 & 0.6 & 0.53 & 180 & 4.5 & 440 \\
\hline HLC-IX & 0.42 & 130 & 20 & 293 & 0.6 & 0.70 & 202 & 4.5 & 450 \\
\hline
\end{tabular}

The table 5 shows that in order to meet the workability of the concrete, the water of the concrete mixture by aggregate air dried is more than aggregate saturated surface dried. Considering the coarse aggregate air dried state with less water, the mixture ratios of the concrete are same no matter the coarse aggregate air dried or saturated surface dried.

4.2.2 The test of the water reducer under the coarse aggregate air dried. The influences of water reducers for concrete on slump loss, gas loss, bleeding rate and the setting time with the coarse aggregate air dried are shown in Table 6.

Table 6 The test result of coarse aggregate in air dry condition

\begin{tabular}{|c|c|c|c|c|c|c|c|c|c|c|c|c|c|c|c|}
\hline \multirow{3}{*}{$\begin{array}{l}\text { Types } \\
\text { of } \\
\text { water } \\
\text { reducer }\end{array}$} & \multirow{3}{*}{$\begin{array}{l}\text { The } \\
\text { machin } \\
\mathrm{e} \\
\text { slump/ } \\
\text { mm }\end{array}$} & \multirow{3}{*}{$\begin{array}{c}\text { Initial } \\
\text { gas } \\
\text { content } \\
/ \%\end{array}$} & \multicolumn{10}{|c|}{ Time $/ \min$} & \multirow{3}{*}{$\begin{array}{l}\text { Bleedi } \\
\text { ng rate } \\
7 \%\end{array}$} & \multicolumn{2}{|c|}{$\begin{array}{c}\text { Setting } \\
\text { time/min }\end{array}$} \\
\hline & & & 0 & 15 & 30 & 45 & \multicolumn{2}{|c|}{60} & \multicolumn{2}{|c|}{90} & \multicolumn{2}{|c|}{120} & & $\begin{array}{c}\text { Initi } \\
\text { al } \\
\text { setti } \\
\text { ng }\end{array}$ & $\begin{array}{c}\text { Final } \\
\text { setti } \\
\text { ng }\end{array}$ \\
\hline & & & $\underset{\mathrm{L}}{\mathrm{S}} \mathrm{G}$ & $\mathrm{S}_{\mathrm{L}} \mathrm{G}$ & $\underset{\mathrm{L}}{\mathrm{S}} \mathrm{G}$ & $\underset{\mathrm{L}}{\mathrm{S}} \mathrm{G}$ & $\begin{array}{l}\mathrm{S} \\
\mathrm{L} \\
\end{array}$ & $\mathrm{G}$ & $\underset{\mathrm{L}}{\mathrm{S}} \mathrm{C}$ & $\mathrm{G}$ & $\begin{array}{l}\mathrm{S} \\
\mathrm{L}\end{array}$ & $\mathrm{G}$ & & 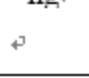 & 5 \\
\hline JG-3 & 195 & 3.0 & 0 & $\begin{array}{ll}4 & 4 \\
7 & 0\end{array}$ & $\begin{array}{ll}5 & 4 \\
9 & 7\end{array}$ & $\begin{array}{ll}6 & 5 \\
9 & 0\end{array}$ & $\begin{array}{l}7 \\
4\end{array}$ & $\begin{array}{l}5 \\
3\end{array}$ & $\begin{array}{l}7 \\
9\end{array}$ & $\begin{array}{l}6 \\
0\end{array}$ & $\begin{array}{l}8 \\
5\end{array}$ & 60 & 5.3 & 645 & 836 \\
\hline $\begin{array}{l}\text { JM-II } \\
(\mathrm{c})\end{array}$ & 178 & 3.9 & 0 & $\begin{array}{ll}4 & 2 \\
4 & 1\end{array}$ & $\begin{array}{ll}6 & 4 \\
3 & 1\end{array}$ & $\begin{array}{ll}6 & 5 \\
9 & 1\end{array}$ & $\begin{array}{l}8 \\
1\end{array}$ & $\begin{array}{l}5 \\
1\end{array}$ & $\begin{array}{l}8 \\
5\end{array}$ & $\begin{array}{l}5 \\
1\end{array}$ & $\begin{array}{l}8 \\
9\end{array}$ & 54 & 9.1 & 796 & 916 \\
\hline $\begin{array}{c}\mathrm{HLC}-\mathrm{N} \\
\mathrm{AF}\end{array}$ & 186 & 3.0 & 0 & $\begin{array}{ll}3 & 2 \\
5 & 3\end{array}$ & $\begin{array}{ll}5 & 5 \\
6 & 0\end{array}$ & $\begin{array}{ll}6 & 5 \\
4 & 3\end{array}$ & $\begin{array}{l}7 \\
5\end{array}$ & $\begin{array}{l}5 \\
7\end{array}$ & $\begin{array}{l}8 \\
0\end{array}$ & $\begin{array}{l}5 \\
7\end{array}$ & $\begin{array}{l}8 \\
4\end{array}$ & 57 & 3.3 & 525 & 680 \\
\hline$\underset{\mathrm{S}}{\text { NOF-A }}$ & 208 & 4.5 & 0 & $\begin{array}{ll}0 & 4 \\
0\end{array}$ & $\begin{array}{ll}3 & 6 \\
3 & 2\end{array}$ & $\begin{array}{ll}5 & 6 \\
2 & 9\end{array}$ & $\begin{array}{l}6 \\
3\end{array}$ & $\begin{array}{l}6 \\
9\end{array}$ & $\begin{array}{l}8 \\
0\end{array}$ & $\begin{array}{l}6 \\
9\end{array}$ & $\begin{array}{l}8 \\
7\end{array}$ & 69 & 6.5 & 536 & 720 \\
\hline $\mathrm{JG}-2 \mathrm{H}$ & 190 & 3 & 0 & $\begin{array}{ll}4 \\
7\end{array} 6$ & $\begin{array}{l}6 \\
6\end{array}$ & $\begin{array}{ll}7 & 2 \\
1 & 2\end{array}$ & $\begin{array}{l}7 \\
8\end{array}$ & $\begin{array}{l}2 \\
2\end{array}$ & $\begin{array}{l}8 \\
6\end{array}$ & $\begin{array}{l}2 \\
2\end{array}$ & $\begin{array}{l}8 \\
7\end{array}$ & 34 & 5.5 & 547 & 720 \\
\hline $\begin{array}{c}\text { JM-PC } \\
\text { A(I) }\end{array}$ & 180 & 4.5 & 0 & $\begin{array}{ll}1 & 0\end{array}$ & $\begin{array}{l}3 \\
6\end{array}$ & $\begin{array}{ll}5 & 1 \\
1 & 3\end{array}$ & $\begin{array}{l}6 \\
4\end{array}$ & $\begin{array}{l}1 \\
6\end{array}$ & $\begin{array}{l}7 \\
5\end{array}$ & $\begin{array}{l}1 \\
8\end{array}$ & $\begin{array}{l}7 \\
9\end{array}$ & 22 & 4.6 & 494 & 655 \\
\hline $\begin{array}{c}\text { HLC-I } \\
\mathrm{X}\end{array}$ & 193 & 4.5 & 0 & 30 & $\begin{array}{l}2 \\
3\end{array}$ & $\begin{array}{l}3 \\
9\end{array}$ & $\begin{array}{l}4 \\
5 \\
\end{array}$ & & $\begin{array}{l}6 \\
9 \\
\end{array}$ & $\begin{array}{l}1 \\
3 \\
\end{array}$ & $\begin{array}{l}7 \\
5 \\
\end{array}$ & 18 & 4.8 & 390 & 541 \\
\hline
\end{tabular}

The gas loss of the concrete of the polycarboxylate-based water reducer is less than naphthalene-based water reducer's. The same type water reducer (NSR or PC) has the same concrete slump loss. The slump loss rate of the concrete by the polycarboxylate-based water reducer is better than naphthalene-based water reducer's within 30mins after mixing. However, after 60mins, it would increase and exceed the naphthalene-based water reducer's. After 120mins, the slump loss rate will be the same about the NSR and PC concrete.

\section{The influences of the pumping concrete workability for later mixing water reducer}

There is a long distance in JinpingII hydropower station tunnel, which causes the damage to the 
concrete slump and gas loss is too large. According to the experimental data, it shows that the water reducers of JM-II(c), HLC-NAF, JM-PCA(I) and HLC-IX have good adaptability for engineering materials used in mixing system. It's necessary to analyze the process of four types of later mixing water reducers.

Determine the mixture ratios of JM-II(c), HLC-NAF, JM-PCA(I) and HLC-IX from table 3 as basic proportions. Add the water reducer and air-entraining agent whose amount matches basic proportion after concrete mixed after 60mins and $120 \mathrm{mins}$. Then analyze the workability of the concrete on three time nodes (So- The machine slump/mm, S- the slump increment/mm, G- gas content/\%).

Table 7 The influence of process of gas content and slump with later mixing additive

\begin{tabular}{|c|c|c|c|c|c|c|c|c|c|c|c|c|c|c|c|c|}
\hline \multirow{2}{*}{ Water reducer } & \multicolumn{2}{|c|}{$0 \min$} & \multicolumn{2}{|c|}{$15 \mathrm{mins}$} & \multicolumn{2}{|c|}{ 30mins } & \multicolumn{2}{|c|}{$45 \mathrm{mins}$} & \multicolumn{2}{|c|}{$60 \mathrm{mins}$} & \multicolumn{2}{|c|}{ 90mins } & \multicolumn{2}{|c|}{$120 \mathrm{mins}$} & \multicolumn{2}{|c|}{ 150mins } \\
\hline & $\mathrm{S}_{0}$ & $\mathrm{G}$ & $\mathrm{S}$ & $\mathrm{G}$ & $\mathrm{S}$ & $\mathrm{G}$ & $\mathrm{S}$ & $\mathrm{G}$ & $\mathrm{S}$ & $\mathrm{G}$ & $\mathrm{S}$ & $\mathrm{G}$ & $\mathrm{S}$ & $\mathrm{G}$ & $S$ & $\mathrm{G}$ \\
\hline JM-II（c） & $\begin{array}{c}17 \\
8\end{array}$ & 3.9 & $\begin{array}{c}10 \\
0\end{array}$ & 3.1 & 65 & 2.3 & 55 & 1.9 & 33 & 1.9 & 27 & 1.9 & 19 & 1.8 & - & - \\
\hline JM-II（c） & 0 & 1.0 & 0 & 1.0 & 0 & 1.0 & 0 & 1.0 & $\begin{array}{c}19 \\
5\end{array}$ & 2.8 & $\begin{array}{c}18 \\
0\end{array}$ & 1.8 & 140 & 1.6 & 105 & 1.5 \\
\hline JM-II（c） & 0 & 1.0 & 0 & 1.0 & 0 & 1.0 & 0 & 1.0 & 0 & 1.0 & 0 & 1.0 & 126 & 1.9 & 85 & 1.5 \\
\hline HLC-NA & $\begin{array}{c}18 \\
6\end{array}$ & 3.0 & $\begin{array}{c}12 \\
0\end{array}$ & 2.3 & 82 & 1.5 & 67 & 1.4 & 47 & 1.3 & 38 & 1.3 & 29 & 1.3 & - & - \\
\hline $\mathrm{HI}$ & 0 & 1.0 & 0 & 1.0 & 0 & 1.0 & 0 & 1.0 & $\begin{array}{c}21 \\
5\end{array}$ & 3.8 & $\begin{array}{c}19 \\
9\end{array}$ & 2.4 & 149 & 2.3 & 82 & 2.1 \\
\hline HLC-NAF & 0 & 1.0 & 0 & 1.0 & 0 & 1.0 & 0 & 1.0 & 0 & 1.0 & 0 & 1.0 & 79 & 1.9 & 38 & 1.5 \\
\hline HLC-IX & $\begin{array}{c}20 \\
6\end{array}$ & 4.5 & $\begin{array}{c}20 \\
0\end{array}$ & 4.5 & $\begin{array}{c}15 \\
9\end{array}$ & 4.4 & $\begin{array}{c}12 \\
5\end{array}$ & 4.3 & $\begin{array}{c}11 \\
3\end{array}$ & 4.3 & 64 & 3.9 & 51 & 3.7 & - & - \\
\hline HLC-IX & 0 & 1.0 & 0 & 1.0 & 0 & 1.0 & 0 & 1.0 & $\begin{array}{c}20 \\
5\end{array}$ & 5.0 & $\begin{array}{c}16 \\
8\end{array}$ & 4.8 & 81 & 4.7 & 65 & 4.5 \\
\hline HLC-IX & 0 & 1.0 & 0 & 1.0 & 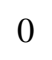 & 1.0 & 0 & 1.0 & 0 & 1.0 & 0 & 1.0 & 60 & 5.0 & 24 & 4.6 \\
\hline JM-PCA（I） & $\begin{array}{c}18 \\
0\end{array}$ & 4.5 & $\begin{array}{c}15 \\
4\end{array}$ & 4.5 & $\begin{array}{c}11 \\
5\end{array}$ & 4.1 & 88 & 3.9 & 65 & 3.8 & 45 & 3.7 & 37 & 3.5 & - & - \\
\hline JM-PCA（I） & 0 & 1.0 & 0 & 1.0 & 0 & 1.0 & 0 & 1.0 & $\begin{array}{c}17 \\
5\end{array}$ & 5.5 & $\begin{array}{c}14 \\
0\end{array}$ & 5.1 & 100 & 4.9 & 69 & 4.7 \\
\hline JM-PCA（I） & 0 & 1.0 & 0 & 1.0 & 0 & 1.0 & 0 & 1.0 & 0 & 1.0 & 0 & 1.0 & 27 & 5.0 & 19 & 4.6 \\
\hline
\end{tabular}

The tests indicate that after adding water reducer in 120mins after concrete mixed, the slump is less than the machine slump and the gas content of the concrete which added air-entraining agent and naphthalene-based water reducer in 120mins after concrete mixed is smaller than which is added the admixture at the mixing time. But instead of the polycarboxylate-based water reducer, the concrete slump which added the admixture at $60 \mathrm{mins}$ and $120 \mathrm{mins}$ is much smaller than the one which added admixtures while mixing, especially at 60mins. It has a good performance of molding.

\section{Conclusions}

According to the tests of different water reducers, there are results confirming that the HLC-IX, JM-PCA(I), and the HLC-IX,JM-II(c) have good adaptability with engineering materials used in mixing system on JinpingII Hydropower Station.

(1). The concrete's gas loss which added the polycarboxylate-based water reducer is much smaller than naphthalene-based water reducer. And its flowability is better but segregation is worse than naphthalene-based water reducer's concrete.

(2). There is a good advantage for pumping concrete workability of concrete mixing 60mins later and then adding water reducer, especially for polycarboxylate-based water reducer.

(3). It's possible to improve the working performance of pumping concrete which is used in JinpingII hydropower station by water reducer.

\section{Acknowledgements}

This work was financially supported by the Subject Foundation of Sichuan Province Education 
Department (16ZB0261);

And also thanks for ChenBo's support whose from Chengdu Engineering Corporation Limited of Power China.

\section{References}

[1]. Kamel K Alzboon, Khalid N Mahasneh. Effect of using stone cutting waste on the compression strength and slump characteristics of concrete[J]. International Journal of Environmental Science and Engineering, Vol. 1, 2009 (4), p.167-172.

[2]. Bahar Demirel. The effect of the using waste marble dust as fine sand on the mechanical properties of the concrete[J]. International Journal of the Physical Science, Vol. 5, 2010 (9), p.1372-1380.

[3]. Cheng W F, He J R, Lin X P. Experimental study of mixing proportion optimization of high performance pumping concrete under long-time transportation[J]. Engineering Journal of Wuhan University, Vol. 47, 2014(1), p: 59-65.

[4]. Ma Y G, Han Q F. Department of mud resistant polycarboxylate-based water reducer of synthesis and application in the PCCP concrete[J]. Water Resources and Hydropower Engineering, Vol. 42, 2016(8), p: 59-62.

[5]. Li K L, Wang Y, Nie W P, etal. Dam concrete prepared using setretarder superplasticizer with low alkali content[J]. Concrete, 2011(5), p. 136-139.

[6]. Xu Y M. Experimental study of carboxylic acid water reducing agent on the properties of concrete[J]. Yangtze River, 2007(3), p. 68-70.

[7]. Yang F L, Ji Y H, Hou G H, etal. Study actuality and development trend of polycarboxylate-based superplasticizer[J]. Journal of materials, 2010(11), p. 436-439.

[8]. Zhang H Y, Zhang B. naphthalene and Polycarboxylic Water Reducing comparison of influence on the performance of concrete[J]. China concrete and cement products, 2011(7), p. 10-12, 16.

[9]. Wang H C, Fang M M, Chen C Q, etal. Effect of PC and NFC water reducers on the property of cement based materials[J]. Concrete, 2009(3), p. 66-69.

[10]. Wang Fulai, Gong Aimin, Peng Yulin, etal. Application Study on curability of Silica Fume Concrete in Fengweihe Hydropwer Station[J]. Journal of Yunnan Agricultural University, Vol. 26, 2011(1), p: 105-109,123. 